\title{
Physical and chemical characteristics of toilet soap made from apricot kernel oil and palm stearin
}

\author{
By Adel Y. Girgis*, N.M. Abd El-Aziz and S.M. Abd El-Salam \\ Oil and Fat Res. Dept., Food Technology Res. \\ Institute, Agricultural Res. Center, 9 El-Gamaa St., Giza, Egypt.
}

\section{RESUMEN}

Características físicas y químicas de jabones de tocador fabricados a partir de aceite de semilla de albaricoque y estearina de palma.

El objetivo del presente trabajo fue el uso del aceite de semilla de albaricoque con estearina de palma en la fabricación de jabón de tocador. El aceite de semilla de albaricoque (Prunus armeniaca) se obtuvo por presión hidráulica $\left(12000 \mathrm{lb} / \mathrm{in}^{2}\right)$, y la semilla contenía el $43.3 \%$ de aceite. Los ácidos grasos del aceite de semilla de albaricoque tenían altos contenidos de ácido oleico (81.73\%) mientras, el ácido graso mayoritario en la estearina de palma fue el ácido palmítico $(55.17 \%)$. Se prepararon ocho muestras de jabón de tocador a partir de aceite de semilla de albaricoque, aceite de semilla de palma y estearina de palma en diferentes proporciones.

La estructura de las muestras de los jabones $n^{\circ} 1$ y 8 fueron viscosas y blandas con malas propiedades físicas. Por otro lado las características fisicas de las mezclas $\mathrm{n}^{\mathrm{os}} 2,3,4,5$ y 6 tuvieron una consistencia firme y espuma cremosa, mientras en el jabón no 7 fueron moderadas, esto es dureza intermedia con espuma adecuada. Después del almacenamiento (6 meses) en estantería a temperatura ambiente, todos los jabones ( $n^{\circ}$ 1-8) disminuyeron su contenido en humedad. Por el contrario, los ácidos grasos totales de las mismas muestras aumentaron en diferente proporción durante el almacenamiento. Las características físicas de las muestras de jabones $n^{0 s} 2,3,4,5,6$ y 7 mejoraron después del tiempo de almacenamiento ( 6 meses), su consistencia fue muy firme con espuma cremosa y se observó una reducción en el desgaste en función del número de lavados.

Se recomienda el uso del aceite de semilla de albaricoque en la fabricación de jabones de tocador hasta una proporción del $50 \%$ de la mezcla grasa (la mezcla fue estearina de palma corriente).

PALABRAS-CLAVE: Aceite de semilla de albaricoque - Estearina de palma - Jabón de tocador - Propiedades físicas.

\section{SUMMARY}

Physical and chemical characteristics of toilet soap made from apricot kernel oil and palm stearin.

The objective of the present work was to use apricot kernel oil with palm stearin in toilet soap-making. Apricot kernel oil was obtained from apricot kernel seed (Prunus armeniaca) through hydraulic pressing $\left(12000 \mathrm{lb} / \mathrm{in}^{2}\right)$. Kernel contained $43.3 \%$ oil. The fatty acids of apricot kernel oil had high oleic acid $(81.73 \%)$ while, the major of the fatty acid in palm stearin was palmitic acid $(55.17 \%)$. Eight of the toilet soap samples were prepared from apricot kernel oil, palm kernel oil and palm stearin at different ratios.
The structure of soap samples $n^{\circ} 1$ and 8 were sticky and with bad physical properties. On the other hand, the physical characteristics of blends $n^{\circ s} 2,3,4,5$ and 6 had firm consistency and creamy lather while, in soap $n^{\circ} 7$, its were moderatement; i. e. medium hard makeup with fairly lather. After storage ( 6 months) on a shelf at room temperature, all soaps ( $\left.n^{\circ}-1-8\right)$ were declined in their moisture content. On contrary, the total fatty acids of the same samples were augmented at different ratios during storage. Physical characteristics of soap samples $n^{o s} 2,3,4,5,6$ and 7 were increased after the storage time (6 months), their consistencies were very firm with creamy lather and reducement in their erosion from handwashing ratios was observed. It can be recommended that apricot kernel oil can be used in the manufacturing of toilet soap until ratio $50 \%$ of the fatty blend (the blend was bear palm stearin).

KEY-WORDS: Apricot Kernel oil - Palm stearin - Physical properties - Toilet soap.

\section{INTRODUCTION}

Apricot (Prunus armeniaca L., Family Rosacease) is grown mainly in El-Delta Governorates, Egypt, while in the world it plants in Turkey, Spain, USA and some European countries as flesh fruit (1). Apricot seed is about $16 \%$ of the total fresh fruit weight (2), while the average of inner kernels are $38 \%$ of the total seed weight (3). The kernel in the stone contains $40-50 \%$ oil (4), while it is a range of $27-67 \%$ (5). In Egypt, cultivated area was 7590 acres of apricot, with total production of 41625 tons in the year of 1994 (6). Apricot are consumed fresh or in processed forms. The seeds are usually separated during processing and considered as a wastes. The total of apricot used for processing in the Egyptian food companies (Governmental and private factories) at 1996 are about 12000 tons (7). This give about 450 tons of apricot kernel oil. Palm stearin, has been widely accepted technology as fatty raw materials by the soap industry, due to its excellent soap making properties and its cost competitiveness to tallow (8-9).

This work was designed to achieve two main aims. The first is to find the best percentage of apricot kernel oil used in the toilet soap manufacture with good quality in their properties, and the second aim is to study the changes in physical and chemical 
characteristics of the obtained soap from apricot kernel oil (up to $60 \%$ from the fatty blend) with palm kernel oil and palm stearin.

\section{MATERIALS AND METHODS}

\subsection{Materials}

Seeds of apricot (Prunus armeniaca) were obtained from the factory of Food Tech. Res. Institute, Agriculture Res. Center, Giza, Egypt, 1995. The obtained seeds were washed in the water, dried in the air, weighed and dehulled. The resulting kernels were weighed and ground using a blender, then sieved to fine particles. The oil was extracted from the ground kernels using hydraulic pressing, $\left(12000 \mathrm{lb} / \mathrm{in}^{2}\right)$ and the resulting oil was stored in dark bottles glass at $-18^{\circ} \mathrm{C}$ until using to make the soap samples.

- Palm kernel oil (P.K.O.) and palm stearin (P.S.) were brought from Cairo Oils and Soap Company, Cairo, Egypt.

- Sodium hydroxide was purchased from Siag Chemicals Company, Cairo, Egypt.

- Sodium chloride was supplied from Cairo local market, Egypt.

\subsection{Methods}

\subsubsection{Determination of chemical and physical properties for oils}

Moisture and volatile matter (\%); acidity (\%) (as oleic acid for apricot kernel oil, while as lauric and palmitic acids for palm kernel oil and palm stearin, respectively); saponification value (S.V.); iodine number as Wij's (I.N.), titer number ${ }^{\circ} \mathrm{C}$ (T.N.) and unsaponifiable matter (\%) were determined according to the methods described in the A.O.C.S. (10), then I.N.S. factor was calculated (as a difference between saponification value and iodine number) according to Webb (11) and Ahmed (12).

\subsubsection{Preparation of fatty acid methyl esters}

The methyl esters of fatty materials [apricot kernel oil (A.K.O.), palm kernel oil (P.K.O.) and palm stearin (P.S.)] were prepared [using benzene: methanol: concentrated sulfuric acid (10: 86: 4) and methylation was carried out for one hour at $\left.80-90^{\circ} \mathrm{C}\right]$ according to Anon (13).

\subsubsection{Identification of fatty acid methyl esters}

Gas-liquid chromatography apparatus (pye- unicam model 4550) was used for the identification of fatty acid methyl esters. The used conditions were identical to that reported by Zygadlo et al., (14). Peak areas were measured using spectrophysic integrator.

\subsubsection{Preparation of soap samples}

Eight samples of soap ( $n$ - 1-8) were made from blend of apricot kernel oil (A.K.O.), palm kernel oil (P.K.O.) and palm stearin (P.S.) at different ratios (Table I). The total amount of oils using for saponify were one kilogram from each of a fatty blend with the ratios shown in Table I, which were saponified with $16 \%$ caustic soda $\left(37^{\circ} \mathrm{Bè}\right)$ on a hot plate $\left(90^{\circ} \mathrm{C}\right)$ laboratory, then $20 \%$ hot water $\left(90^{\circ} \mathrm{C}\right)$ was added to remove excess sodium hydroxide, then spread $8 \%$ dry salt $(\mathrm{NaCl})$ during the soap was boiling over its surface to separate spent lye in the bottom, while saponified mass was floated on the surface. Spent lye was extracted by siphoning. The soap paste was poured in a wood frame and lifted for one day for hardening. The block of soap was cut to small pieces, then stored on a shelf at room temperature. The soap yield from blends $\mathrm{n}^{\mathrm{os}} 2,3,4,5,6$ and 7 were about 1.290, 1.320, 1.330, $1.350,1.370$ and 1.385 kilogram, respectively, while in blends $\mathrm{n}^{\circ} 1$ and 8 were unable to measure their whights because their consistencies had soft and sticky. The produced soap was analyzed for its chemical and physical properties every one month.

Table I

Fatty materials blends used in the soap samples (\% as W/W)

\begin{tabular}{|c|c|c|c|c|c|c|c|c|}
\hline \multirow{2}{*}{$\begin{array}{c}\text { Fatty } \\
\text { materials }\end{array}$} & \multicolumn{7}{|c|}{${\text { Fat blends } n^{2}}^{\prime}$} \\
\cline { 2 - 10 } & 1 & 2 & 3 & 4 & 5 & 6 & 7 & 8 \\
\hline $\begin{array}{c}\text { Apricot kemel oil } \\
\text { (A.K.O.) }\end{array}$ & 100 & - & 10 & 20 & 30 & 40 & 50 & 60 \\
\hline $\begin{array}{c}\text { Palm kernel oil } \\
\text { (P.K.O.) }\end{array}$ & - & 15 & 15 & 15 & 15 & 15 & 15 & 15 \\
\hline Palm stearin (P.S.) & - & 85 & 75 & 65 & 55 & 45 & 35 & 25 \\
\hline
\end{tabular}

\subsubsection{Estimation of chemical and physical properties for the derived soaps}

Moisture (\%), total fatty acids (T.F.A.\%), free alkali ( $\mathrm{Na} \mathrm{OH} \%$ ), free oil (\%) and titer number ${ }^{\circ} \mathrm{C}$ (T.N.) of the investigated soaps were determined according to the methods described by the Egyptian Standards (15) and the A. O.C. S. (10). Hand lather preference and erosion from handwashing of soap samples were estimated according to Ginn et,al., (16), while the consistency of derived soap was evaluated according to Martin (17). 


\section{RESULTS AND DISCUSSION}

\subsection{Composition of fruit apricot}

The percentage of pulp in fresh apricot was $82 \%$, while the seed formed about $18 \%$. These values were not in accordance with those reported by Hallabo (18), who found $85 \%$ and $15 \%$ for pulp and seed, respectively. This different might be owing to the difference in the varieties used. The kernel in seed was about $40.0 \%$. This value was close to that $(38.0 \%)$ obtained by Sarhan (2). While oil content in the kernel was $43.3 \%$, this result was within the range (40-45\%) obtained by Hallabo (18) but this ratio was lower than that $(50.5 \%)$ reported by Awatif and Badawy (19). The differences in the values almost related to apricot varieties differences.

Table II

Some properties of fatty materials used in the samples of soap

\begin{tabular}{|c|c|c|c|c|c|c|c|}
\hline Character & $\begin{array}{c}\text { Moisture } \\
\text { and volatile } \\
\text { matter } \%\end{array}$ & Acidity \% & $\begin{array}{c}\text { Saponification } \\
\text { value } \\
\text { (S.V.) }\end{array}$ & $\begin{array}{c}\text { lodine } \\
\text { value } \\
\text { (I.V.) }\end{array}$ & $\begin{array}{c}\text { I.N.S. } \\
\text { Factor }\end{array}$ & $\begin{array}{c}\text { Titer number } \\
\text { (T.N.) }{ }^{\circ} \mathrm{C}\end{array}$ & $\begin{array}{c}\text { Unsaponifiable } \\
\text { matter } \\
(\%)\end{array}$ \\
\hline A.K.O. & 0.21 & 0.80 (oleic) & 188.9 & 88.2 & 100.7 & 14.2 & 0.82 \\
\hline P.K.O. & 0.10 & 0.21 (lauric) & 244.5 & 17.0 & 227.5 & 27.0 & 0.12 \\
\hline P.S. & 0.11 & 0.12 (palmitic) & 203.4 & 36.2 & 167.2 & 50.5 & 0.13 \\
\hline
\end{tabular}

A.K.O.: Apricot kernel oil

Results in Table II appeared some physical and chemical properties of oils used in this study. Moisture and volatile matter, acidity, saponification value, iodine number, I.N.S. factor, titer number and unsaponifiable matter of A.K.O. and P.K.O. were previously discussed in part I by Girgis and Khalil (20). Moisture and volatile matter of P.S. was within the range (should be less than $0.3 \%$ ) of that reported by Ministry of Industry (21). The acidity of P.S. was lower than the range $(2.0-2.9 \%$ as free fatty acid) obtained by Tan et al., (22). While, saponification value (S.V. is used to estimate the quantity of sodium hydroxide required to saponify the fat), iodine number, (indicative to unsaturated fatty acid), I.N.S. factor and T.N. of the same oil were within the range (193-206, 22-48, $160-171$ and $46-54^{\circ} \mathrm{C}$ for S.V., I.N., I.N.S. factor and T.N., respectively) of those found by the other authors [Ahmed (8-12) and Bhattacharyya and Chatterjee (23)]. Woollatt (24) noticed that I.N.S. factor should be not less than 130 until give a good consistency of soap. Also from Table II, unsaponifiable matter (the portion does not react with alkali during the saponification) of P. S. was within the range of that reported by Ministry of Industry (21), who stated that it should be less than $0.3 \%$ for all the oils and fats using in the manufacturing of soap in Egypt.

\subsection{Fatty acid composition of fatty materials used in the produced soap}

Table III shows that 9 fatty acids for A.K.O., P.K.O. and P.S. The Fatty acid compositions of A.K.O. and P.K.O. were already mentioned by Girgis and Khalil (20). From this Table, it can be observed that P.S. contained higher amount of saturated fatty acids $(62.97 \%)$ than unsaturated fatty acids $(37.03 \%)$, and the major unsaturated fatty acid was oleic acid (29.93\%), while palmitic acid was the predominant saturated fatty acid $(55.17 \%)$. These values were consentment with that obtained by Ahmed (8-12).

Table III

Fatty acid composition of apricot kernel oil, palm kernel oil and palm stearin

\begin{tabular}{|c|c|c|c|c|c|c|c|c|c|c|}
\hline Oils & $C_{8: 0}$ & $C_{10: 0}$ & $C_{12: 0}$ & $C_{14: 0}$ & $C_{16: 0}$ & $C_{16: 1}$ & $C_{18: 0}$ & $C_{18: 1}$ & $C_{18: 2}$ & $\begin{array}{c}\text { Total unsaturated } \\
\text { fatty acids } \%\end{array}$ \\
\hline A.K.O & 1.04 & - & 0.94 & 2.10 & 5.80 & 1.21 & 1.35 & 81.73 & 5.83 & 88.77 \\
\hline P.K.O & 5.30 & 6.11 & 52.90 & 14.22 & 7.06 & - & 2.91 & 9.14 & 2.36 & 11.50 \\
\hline P.S. & - & - & 0.40 & 1.25 & 55.17 & - & 6.15 & 29.93 & 7.10 & 37.03 \\
\hline
\end{tabular}




\subsection{Properties of the soap samples}

Data presented in Table IV indicate that some physical and chemical properties of the consequent soaps $\left(n^{\circ} 1-8\right)$. Results of soap $n^{\circ} 1$ were above discussed in part I by Girgis and Khalil (20). While the moisture contents of 7 soap samples (from $n^{\circ} 2$ to 8 ) were in accordance with those $(30 \%)$ obtained by Martin (17), while their T.F.A. were higher than that $(63.5 \%)$ reported by Monticelli (25). Moreover, free alkali $(\mathrm{Na} \mathrm{OH})$ of the same soaps were in match with the range (should be less than $0.33 \%$ as $\mathrm{NaOH}$ ) given by The Egyptian Standards (15), except free alkali in sample no $8(0.37 \%)$, which was higher. These risement almost related to the high percentage of A.K.O. used (60\%). The free oils of the same samples were in agreement with that (less than $0.5 \%$ ) assigned by The Egyptian Standards (15) except in soap no $8(0.52 \%)$, which was higher. This difference may be in consideration of the unsaponifiable matter in A.K.O. (0.92\%). On the other hand, T.N. of the soap samples $n^{\circ} 2,3$ and 4 were higher than that in European toilet soap $\left(30-38^{\circ} \mathrm{C}\right)$ which given by Ainie et al., (26). These increment may by assigned to T.N. of P.S. $\left(50.5^{\circ} \mathrm{C}\right)$, but T.N. of soap $n^{\circ} 3$ was coincide with the range $\left(40-42^{\circ} \mathrm{C}\right)$ found by Bhattacharyya and Chatterjee (23). Therefore, these results gave very hard consistency with creamy foam and decrement in erosion from handwashing of 6 soap samples (from $\mathrm{n}^{\circ}$ 2 to 7). The above-mentioned results could be attributed to the presence of A.K.O. at a concentration of $50 \%$ of the total fatty blend. Therefore, samples of soap (from $n^{\circ} 2$ to 7 ) were suitable for use. On contrary, soap no 8 was soft and a sticky consistency with bad physical properties, there on, it was out of character for use. This was probably owing to the high percentage of A.K.O. was used $(60 \%)$, which was higher than that the using in 6 soap blends (from no 2 to 7). These results were coincide with that obtained by Girgis and Khalil (20), who pointed out that the produced soap from A.K.O. (up to $40 \%$ ) with tallow gave good quality; i.e. hard consistency with rich foam.

Table IV

Properties of soap samples manufacturated from different ingredients

\begin{tabular}{|c|c|c|c|c|c|c|c|c|}
\hline \multirow{2}{*}{$\begin{array}{c}\text { Soap } \\
\text { samples } \\
\mathrm{n}^{\circ}\end{array}$} & \multicolumn{4}{|c|}{ Chemical properties } & \multicolumn{4}{c|}{ Physical properties } \\
\cline { 2 - 9 } & $\begin{array}{c}\text { Moisture } \\
\%\end{array}$ & $\begin{array}{c}\text { T.F.A. } \\
\%\end{array}$ & $\begin{array}{c}\text { Free alkali } \\
(\mathrm{NaOH})\end{array}$ & $\begin{array}{c}\text { Free oil } \\
\%\end{array}$ & T.N. $\left({ }^{\circ} \mathrm{C}\right)$ & $\begin{array}{c}\text { Hand lather } \\
\text { preference }\end{array}$ & $\begin{array}{c}\text { Erosion from } \\
\text { handwashing }\end{array}$ & Consistency \\
\hline $\mathbf{1}$ & 35.7 & 55.7 & 0.55 & 0.90 & 14.2 & unable & unable & soft \\
\hline $\mathbf{2}$ & 18.7 & 71.5 & 0.23 & 0.17 & 47.1 & low & high & too much firm \\
\hline $\mathbf{3}$ & 19.9 & 70.0 & 0.24 & 0.23 & 43.3 & medium & medium & very firm \\
\hline $\mathbf{4}$ & 20.7 & 69.5 & 0.25 & 0.31 & 40.0 & good & low & firm \\
\hline $\mathbf{5}$ & 21.8 & 68.3 & 0.28 & 0.33 & 37.9 & excellent & very low & firm \\
\hline $\mathbf{6}$ & 22.6 & 67.5 & 0.30 & 0.43 & 32.2 & good & fairly & firm \\
\hline $\mathbf{7}$ & 24.0 & 66.8 & 0.33 & 0.50 & 28.9 & fairly & medium & firm \\
\hline $\mathbf{8}$ & 26.7 & 65.1 & 0.37 & 0.52 & 25.1 & unable & unable & sticky \\
\hline
\end{tabular}

\subsection{The chemical and physical properties of soap samples during storage ( 6 months) at room temperature}

From data obtained in Table $\mathrm{V}$ it can be observed that the decrements of moisture content in eight soaps were clear during storage from $35.7,18.7,19.9,20.7,21.8$, $22.6,24.0$ and $25.7 \%$ at the start of storage to $26.9,11.1$, $11.5,12.2,12.5,13.2,14.3$ and $15.5 \%$, respectively at the end of storage. These deficiencies were bearable owing to the rate of loss in free water was high during storage, while T.F.A. of the same samples (from $n^{\circ} 1$ to 8 ) were increased from 55.7, 71.5, 71.0, 69.9, 68.8, 68.1, 66.8 and $65.1 \%$ at zero time to $64.1,74.1,78.5,78.1$, $77.9,77.1,76.1$ and $75.1 \%$, respectively after storage time (6 months). These rises seem to be attributed to evaporation of moisture during storage period occurred.
Concerning structure of soap samples $\mathrm{n}^{\circ} 1$ and 8 , which were soft with sticky. This was perhaps in view of the high percentage of A.K.O. used (100 and 60\%), there at these trials ( $n^{\circ} 1$ and 8 ) occurred diminishment in their T.N. $\left(14.2\right.$ and $\left.25.1^{\circ} \mathrm{C}\right)$ than that in European toilet soap $\left(30-38^{\circ} \mathrm{C}\right)$ which reported by Ainie et al., (26). Hand lather and erosion from handwashing of samples $n^{\circ} 1$ and 8 were unable to determine because their structures had soft and sticky, while in samples $n^{\circ s} 2,3,4,5,6$ and 7 were improved in their physical properties after storage, i.e. the foam was creamy and erosion diminishment with firmness in their bodies. These results suspect related to the rises in T.F.A. during storage time.

From the above mentioned data, it could be concluded that apricot kernel oil can be use in the manufacturing of toilet soap up to $50 \%$ of the fatty blend (the blend was containing of palm stearin). 
Table V

Chemical and physical changes occurred in the properties of soap samples during storage for 6 months at room temperature

\begin{tabular}{|c|c|c|c|c|c|c|c|c|c|c|c|c|c|c|c|c|c|}
\hline \multicolumn{18}{|c|}{ The storage time (months) } \\
\hline Parameters & \multicolumn{2}{|c|}{ Zero time } & \multicolumn{2}{|c|}{1} & \multicolumn{2}{|c|}{2} & \multicolumn{2}{|c|}{3} & \multicolumn{2}{|c|}{4} & \multicolumn{2}{|c|}{5} & \multicolumn{5}{|c|}{6} \\
\hline & $\begin{array}{c}\text { Moist. } \\
\%\end{array}$ & $\begin{array}{c}\text { T.F.A. } \\
\%\end{array}$ & $\begin{array}{c}\text { Moist. } \\
\%\end{array}$ & $\begin{array}{c}\text { T.F.A. } \\
\%\end{array}$ & $\begin{array}{c}\text { Moist. } \\
\%\end{array}$ & $\begin{array}{c}\text { T.F.A. } \\
\%\end{array}$ & $\begin{array}{c}\text { Moist. } \\
\%\end{array}$ & $\begin{array}{c}\text { T.F.A. } \\
\%\end{array}$ & $\begin{array}{c}\text { Moist. } \\
\%\end{array}$ & $\begin{array}{c}\text { T.F.A. } \\
\%\end{array}$ & $\begin{array}{c}\text { Moist. } \\
\%\end{array}$ & $\begin{array}{c}\text { T.F.A.A. } \\
\%\end{array}$ & $\begin{array}{c}\text { Moist. } \\
\%\end{array}$ & $\begin{array}{l}\text { T.F.A. } \\
\%\end{array}$ & $\begin{array}{c}\text { Hand } \\
\text { lather } \\
\text { preference }\end{array}$ & $\begin{array}{c}\text { Erosion } \\
\text { from } \\
\text { handwashing }\end{array}$ & Consistency \\
\hline 1 & 35.7 & 55.7 & 32.2 & 58.9 & 30.1 & 62.2 & 28.4 & 63.1 & 27.3 & 63.9 & 26.9 & 64.1 & 26.9 & 64.1 & unable & unable & Soft \\
\hline 2 & 18.7 & 71.5 & 16.7 & 73.8 & 13.6 & 76.8 & 12.5 & 77.1 & 11.2 & 79.1 & 11.1 & 79.1 & - & - & medium & medium & too much firm \\
\hline 3 & 19.9 & 71.0 & 17.3 & 73.0 & 13.7 & 76.7 & 12.8 & 76.8 & 12.0 & 78.1 & 11.5 & 78.5 & 11.5 & 78.5 & failly & fairly & too much firm \\
\hline 4 & 20.7 & 69.9 & 18.1 & 72.2 & 14.7 & 76.0 & 13.6 & 76.6 & 12.9 & 72.1 & 12.3 & 78.1 & 12.2 & 78.1 & very good & very low & very firm \\
\hline 5 & 21.8 & 68.8 & 18.9 & 72.0 & 14.9 & 75.5 & 13.9 & 76.1 & 13.1 & 77.0 & 12.5 & 77.9 & 12.5 & 77.9 & too excellent. & too very low & very firm \\
\hline 6 & 22.6 & 68.1 & 19.9 & 71.8 & 15.7 & 75.3 & 14.4 & 76.1 & 13.6 & 76.8 & 13.2 & 77.2 & 13.2 & 77.1 & very good & low & very fim \\
\hline 7 & 24.0 & 66.8 & 20.5 & 71.1 & 16.1 & 74.0 & 14.8 & 75.3 & 13.9 & 76.0 & 14.3 & 76.1 & 14.3 & 76.1 & good & fairly & very firm \\
\hline 8 & 25.7 & 65.1 & 22.9 & 68.0 & 18.4 & 72.2 & 16.9 & 74.1 & 15.9 & 75.0 & 15.7 & 75.1 & 15.5 & 75.1 & unable & unable & sticky \\
\hline
\end{tabular}

\section{REFERENCES}

1. Salunkhe, D.K., Chavan, J.K., Adsule, R.W. y Kadam, S.S. (1992).-World oilseeds, chemistry technology and utilization.-Published by Van Nostrand Reinhold, New York, p. 561.

2. Sarhan, M.A.I. (1971).-Studies on the production of apricot juice.-M. Sc. Thesis, Faculty of Agric., Cairo Univi., Giza, Egypt, p. 51.

3. Naveen, K., Bedi, K.L. y Bhatia, A.K. (1987).Chemical composition of different varieties of apricots and their kernels grown in Ladakha region.-J. Food Sci. Technol., India 24 (3) 141-142.

4. Vaughan, T.G. (1970). - The structure and utilization of oil seed.-London, Chapman, pp. 201-205.

5. Kapoor, N., Bedi, K.L. y Bhatia, A.K. (1987).Chemical composition of different varieties of apricots and their kernels grown in Ladakha region.-J. Food Sci. Technol., India 24 (3) 141-142.

6. Ministry of Agriculture (1994). - The annual report of central department of agricultural Economics. El Cairo, Egypt.

7. Ministry of Industry (1996).- The annual report of the Egyptian industrials foods organization.-El Cairo, Egypt.

8. Ahmed, I. (1984).--Significance of palm oil and palm stearin as fatty raw materials for soap, PORIM, occasional paper no 19.-Palm Oil Research Institute of Malaysia, Selangor, Malaysia, pp. 1-17.

9. Gunstone, F.D. (1987).-Palm oil.-Published by the Society of Chemical Industry, New York, p. 96.

10. A.O.C.S. (1993).-Official and Tentative Methods for the American Oil Chemists'Society, $6{ }^{\mathrm{th}}$ ed.-Published by the American Oil Chemists'Society. Champaign.

11. Webb, E.T. (1927).-Modern soap and glycerine manufacture.-Davis Brothers, London, pp. 210-213.

12. Ahmed, I. (1981).- -Use of palm stearin in soap, PORIM, occasional paper $n=2$.-Palm Oil Research Institute of Malaysia, Selanger, Malaysia, pp. 1-9.
13. Anon (1966).-Preparation of methyl esters of long-chain fatty acids.-Journal of the American Oil Chemists'Society 43, 40-41.

14. Zygadlo, J.A., Morero, R.E. Abburra, R.E. y Guzman, C.A. (1994).-Fatty acid composition in seed oils of some onagraceae.-Journal of the American Oil Chemists'Society 71, 915-916.

15. The Egyptian Standards, Egyptian Standards (1044/ 1992) for soap, Egyptian Organization for Standardization and Quality Control, Ministry of Industry, Cairo, Egypt (1992).

16. Ginn, M.E., Steinhauer, R.C., Liebman, D. y Eungermann, E. (1968).-Effect of tallow-coconut fatty acid ratios on properties of bar soaps.-Journal of the American Oil Chemists'Society 45, 666-669.

17. Martin, G. (1951).- The modern soap and detergent industry.-The Tech. Press Ltd., London, Vol. 2, p. 5.

18. Hallabo, S.A. (1972).-Chemical and biological evaluation of apricot kernel oil and cake.-M. Sc. Thesis, Faculty of Agric., Cairo Univ., Egypt, pp. 68-69.

19. Awatif, I.I. y Badawy, H.A. (1990).-Utilization of apricot kernel, some characteristics of apricot kernel oil.-Zagazig J. Agric. Res., Egypt, 17 (4) 1213-1217.

20. Girgis, A.Y. y Khalil, M.F. (1997).-Utilization of apricot kernel oil in the manufacturing of toilet soap, Part I. Effect of using apricot kernel oil with tallow on quality and properties of the produced toilet soap.-Arab Univ. J. Agric. Sci., Faculty of Agric., Ain Shams Univ., El Cairo, Egypt 5 (2) 297-308.

21. Ministry of Industry (1991).-The annual report of the Egyptian industrials foods organization, El Cairo, Egypt.

22. Tan, B.K., Oh, F.C.H.I., Siew, W.L. y Berger, K.G. (1983).-Characteristics of processed palm oils, in: palm oil product technology in the eighties.Published by E. Pusparajah, Kuala Lumpur.

23. Bhattacharyya, D.K. y Chatterjee, B. (1984)._-Palm oil fatty acids in soap and detergent formulations.Journal of the American Oil Chemists'Society 61, 417-419. 
24. Woollatt, E. (1985).--The manufacture of soaps, other detergents and glycerine. $1^{\mathrm{st}}$.-Ed. Ellis Horwood Ltd. Chester, England, p. 126.

25. Monticelli, L.J. (1983).-Energy saving in the soap industry.-In: Fat science 1983 proceedings of the $16^{\text {th }}$ $1^{\text {st }}$ congress, Budapest, Hungary 4-7 October.

26. Ainie, K., Hamirin, K. y Peang-Kean, L. (1996).Chemical and physical characteristics of soap made from distilled fatty acids of palm oil and palm kernel
oil.-Journal of the American Oil Chemists' Society 73, 105-108.

Recibido: Octubre 1997 Aceptado: Febrero 1998 